\title{
ANALISIS PENGARUH LITERASI KEUANGAN, FINANCIAL TECHNOLOGY, DAN DEMOGRAFI TERHADAP INKLUSI KEUANGAN PADA MASYARAKAT DI KOTA SURABAYA
}

\author{
Adinda Novita Sari \\ Universitas Negeri Surabaya \\ adindanovita41@gmail.com \\ Achmad Kautsar \\ Universitas Negeri Surabaya \\ achmadkautsar@unesa.ac.id
}

Abstract

\begin{abstract}
Financial inclusion is one of the interesting discussions in global economic development. Indonesia is a country in ASEAN which has the most rapid increase in financial inclusion in recent years. In the era of the industrial revolution 4.0, everyone is required to be able to follow the development of existing technology and information. This study aims to determine the influence of independent variables (financial literacy, financial technology, demographics) on the dependent variable (financial inclusion) in the City of Surabaya. This study is a causality study with quota sampling. The data of this study is quantitative by collecting data by questionnaire. The data analysis technique used is multiple linear regression. The result of this study based on t statistical tests show that financial literacy, age, and education have a positive effect on financial inclusion. While the variables financial technology, gender, and income did not affect on financial inclusion. Based on the statistical test $f$, all of the independent variables simultaneously influence the dependent variable (financial inclusion).
\end{abstract}

Keywords: financial inclusion; financial literacy; financial technology.

\section{PENDAHULUAN}

Topik mengenai financial inclusion atau inklusi keuangan menjadi salah satu perhatian dunia sejak terjadi krisis ekonomi Amerika Serikat tahun 2008. Indonesia merasakan dampak krisis tersebut dengan mengalami penurunan pertumbuhan ekonomi sebesar 1,38\% dari tahun 2008-2009 (Uchoa, 2018). Data dari Global Findex (Global Financial Inclusion Database) yang dipublikasikan pada tahun 2011 menunjukkan bahwa salah satu negara berkembang di dunia termasuk Indonesia memiliki tingkat inklusi keuangan yang cukup rendah yakni sebesar 19,6\% (Demirgüç-Kunt et al., 2018). Beberapa upaya mulai dilakukan oleh pemerintah pada tahun 2012 melalui Strategi Nasional Keuangan Inklusif (SNKI). Dalam rangka meningkatkan kesejahteraan masyarakatnya, tingkat inklusi keuangan Indonesia berhasil naik hingga mencapai jumlah 67,8\% pada tahun 2016 (OJK, 2017).

Peningkatan inklusi keuangan di Indonesia yang begitu memuaskan, tidak menjamin bahwa kesejahteraan masyarakatnya telah merata. Hal tersebut ditunjukkan oleh data survei yang dilakukan oleh OJK (2017), sebanyak 18 provinsi dari jumlah 34 provinsi yang ada di Indonesia mempunyai tingkat inklusi keuangan di bawah rata-rata nasional. Hal ini dapat diartikan bahwa lebih dari setengah jumlah provinsi di Indonesia belum memiliki tingkat inklusi keuangan yang baik.

Provinsi Jawa Timur adalah salah satu provinsi dengan tingkat inklusi keuangan yang berada pada posisi melebihi angka rata-rata nasional yakni sebesar 73,2\% (OJK, 2017). Provinsi Jawa Timur juga memiliki tingkat pertumbuhan ekonomi yang tinggi yaitu sebesar 5,52\% dan angka tersebut bahkan melampaui tingkat pertumbuhan nasional pada tahun 2019 yang hanya mencapai 5,02\% (Widarti, 2020). Namun kondisi tersebut berbanding terbalik dengan data BPS yang menunjukkan bahwa provinsi yang menduduki posisi pertama yang memiliki jumlah penduduk dalam kategori miskin terbanyak di Indonesia ialah Provinsi Jawa Timur, dengan jumlah sebesar 4,11 juta jiwa (Kusnandar, 2019). Perbedaan kondisi tersebut menunjukkan bahwa masyarakat di Provinsi Jawa Timur masih belum merata dalam hal kesejahteraan keuangannya. 
Adinda Novita Sari \& Achmad Kautsar. Analisis Pengaruh Literasi Keuangan, Financial Technology, dan Demografi terhadap Inklusi Keuangan pada Masyarakat di Kota Surabaya

Kota Surabaya yang berkedudukan sebagai Ibu Kota Provinsi Jawa Timur, merupakan daerah yang dijadikan sebagai gerbang perdagangan utama di wilayah Indonesia Timur (Hanung, 2018). Berperan sebagai Kota Metropolitan terbesar kedua di Indonesia, Kota Surabaya memposisikan diri sebagai pusat perdagangan, jasa, dan industri dengan pertumbuhan ekonomi paling pesat di Jawa Timur. Hal tersebut didukung oleh data dari BPS, bahwa Kota Surabaya mengalami pertumbuhan ekonomi sebesar 6,13\% sehingga capaian tersebut melampaui pertumbuhan ekonomi provinsi maupun nasional (Hanung, 2018). Namun di balik kemajuan infrastruktur dan pertumbuhan perekonomiannya, Kota Surabaya justru memiliki tingkat inklusi keuangan yang paling rendah di Jawa Timur (Sari, 2017). Rata-rata inklusi keuangan di Povinsi Jawa Timur mencapai angka 0,8, namun Kota Surabaya hanya memiliki tingkat inklusi keuangan sebesar 0,6 dan yang paling tinggi adalah Kota Mojokerto yakni sebesar 0,9 (Sari, 2017).

Inklusi keuangan didefinisikan sebagai suatu kondisi pada saat produk dan layanan jasa keuangan dapat diakses, digunakan, dan dimanfaatkan dengan harga yang terjangkau dan kualitas yang baik serta ketersediaannya dapat diberikan kepada semua orang untuk meningkatkan kesejahteraannya (Gardeva \& Rhyne, 2011). Dengan adanya inklusi keuangan yang optimal, diharapkan mampu mewujudkan percepatan pertumbuhan ekonomi, pembangunan berkelanjutan, dan meningkatkan kesejahteraan masyarakat secara merata (OJK, 2017).

Variabel pertama yang hendak diteliti ialah literasi keuangan. Literasi keuangan diartikan sebagai suatu bentuk kemampuan individu untuk dapat mengetahui dan memahami tentang persepsi dan risiko keuangan, ketrampilan, dan keyakinan diri untuk dapat mengambil keputusan yang tepat dalam rangka memajukan kesejahteraan keuangan pribadinya (OECD, 2016). Apabila seseorang memahami tentang pengetahuan keuangan, maka akan tertarik untuk memanfaatkan berbagai macam produk serta layanan keuangan yang tersedia secara lebih efektif (OJK, 2017). Yakubu et al. (2017), Mindra \& Moya (2017), Bongomin et al. (2016), Saputra \& Dewi (2017), Hutabarat (2018), serta Pulungan \& Ndruru (2019) menemukan hasil positif dan signifikan antara literasi keuangan dan inklusi keuangan.

Variabel kedua yang akan diteliti yaitu financial technology. Financial Technology diartikan sebagai bentuk penggabungan seluruh sektor teknologi pada bidang keuangan yang digunakan untuk memfasilitasi kegiatan jual beli dan aktivitas bisnis dalam bentuk layanan untuk penggunanya (Ion \& Alexandra, 2016). Tersedianya fitur dan layanan keuangan yang canggih memberikan kemudahan untuk dapat dimanfaatkan oleh masyarakat (Wildan, 2019). Hasil riset Fanta \& Makina (2019), Durai \& Stella (2019), dan Hutabarat (2018) menemukan hasil positif antara financial technology dengan inklusi keuangan. Sedangkan Michelle (2016) menunjukkan bahwa financial technology secara negatif dan tidak berpengaruh signifikan terhadap inklusi keuangan.

Variabel ketiga yang akan diteliti yaitu jenis kelamin. Jenis kelamin didefinisikan sebagai perbedaan biologis, berlaku universal, dan tidak dapat diubah, yang dibagi menjadi dua jenis yakni laki-laki dan perempuan (Nadliroh, 2017). Seorang laki-laki dalam sebuah rumah tangga memiliki kedudukan sebagai kepala keluarga, mempunyai tanggung jawab dalam segala pengambilan keputusan sehingga lebih mungkin untuk dapat memiliki sikap dan tindakan yang lebih rasional (Rizaldi \& Asandimitra, 2019). Hasil riset Fungáčová \& Weill (2014), Zins \& Weill (2016), serta Cámara \& Tuesta (2016) menemukan hasil positif bahwa seorang laki-laki lebih baik untuk dapat terinklusi keuangannya. Sedangkan Abel et al. (2018) menemukan hasil signifikan negatif, di mana perempuan lebih baik terhadap inklusi keuangan. Hasil lain ditemukan oleh Akileng et al. (2018) dan Nugroho \& Purwanti (2017) yang menunjukkan perbedaan jenis kelamin tidak memiliki pengaruh terhadap inklusi keuangan seseorang.

Variabel keempat yang akan diteliti ialah usia. Usia didefinisikan sebagai ukuran yang menggambarkan lamanya masa hidup seseorang yang dihitung sejak waktu kelahiran hingga berulang tahun (Isnandar, 2019). Seiring bertambahnya usia, seseorang akan memiliki tingkat kematangan berpikir dengan baik dalam pengelolaan keuangannya. Hasil riset Akileng et al. (2018), Zins \& Weill (2016), Abel et al. (2018), Tuesta et al. (2015), Fungáčová \& Weill (2014), Hutabarat (2018), serta Nugroho \& Purwanti (2017) menemukan hasil positif, yakni semakin dewasa seseorang, maka lebih banyak faktor 
kemungkinannya untuk terinklusi keuangannya. Sedangkan Roy \& Chaterjee (2016) menemukan hasil signifikan negatif dari pengaruh usia terhadap inklusi keuangan.

Variabel kelima yang akan diteliti yaitu pendapatan. Pendapatan adalah sejumlah penghasilan atau gaji yang diterima oleh seseorang atas pekerjaan atau usahanya (Isnandar, 2019). Apabila pendapatan seseorang tinggi, maka akan mendorong seseorang untuk mengelola keuangannya secara efektif dengan produk dan layanan keuangan yang tersedia (Nugroho \& Purwanti, 2017). Fungáčová \& Weill (2014), Akileng et al. (2018), Roy \& Chaterjee (2016), Wokabi \& Fatoki (2019), Zins \& Weill (2016), Abel et al. (2018), Cámara \& Tuesta (2016), Sahoo et al. (2017), Tuesta et al. (2015), dan Nugroho \& Purwanti (2017) menemukan hasil positif dan secara signifikan antara pendapatan terhadap inklusi keuangan. Sedangkan menurut Hutabarat (2018), tingkat pendapatan yang tinggi tidak menjadi faktor yang berpengaruh terhadap inklusi keungan seseorang.

Variabel keenam yang akan diteliti yakni tingkat pendidikan. Tingkat pendidikan didefinisikan sebagai suatu tahapan pendidikan berkesinambungan yang telah ditempuh oleh seseorang (Krisnakai, 2017). Semakin tinggi tingkat pendidikan seseorang, maka kemampuan dalam pengelolaan keuangannya akan lebih baik juga untuk dapat menggunakan produk dan layanan keuangan yang ada (Abel et al., 2018). Hasil riset Fungáčová \& Weill (2014), Roy \& Chaterjee (2016), Zins \& Weill (2016), Abel et al. (2018), Cámara \& Tuesta (2016), Sahoo et al. (2017), Tuesta et al. (2015), Nugroho \& Purwanti (2017), dan Khoirunnisa (2018) menemukan hasil positif antara tingkat pendidikan dengan inklusi keuangan. Sedangkan Akileng et al. (2018) menemukan hasil yakni tingkat pendidikan tidak memiliki pengaruh terhadap inklusi keuangan.

Penelitian ini masih layak dilakukan karena menggabungkan variabel keperilakuan dengan variabel karakteristik individu untuk diukur pengaruhnya terhadap variabel inklusi keuangan, di mana hal tersebut tidak banyak dilakukan oleh penelitian lain. Selain itu, hasil penelitian terdahulu juga masih terdapat gap. Penelitian ini dilakukan dengan tujuan untuk menganalisis pengaruh literasi keuangan, financial technology, jenis kelamin, usia, pendapatan, dan tingkat pendidikan seseorang terhadap inklusi keuangan. Sehingga, apabila penelitian ini dilakukan pada waktu dan sekelompok orang di daerah yang berbeda, maka akan memungkinkan mendapatkan hasil yang berbeda pula

\section{KAJIAN PUSTAKA DAN PENGEMBANGAN HIPOTESIS}

\section{Theory of Planned Behavior (TPB)}

Theory of Planned Behavior merupakan teori yang menyatakan bahwa seseorang dalam berperilaku pasti dilandasi oleh suatu keyakinan atas informasi yang telah diperoleh (Ajzen, 1991). Dalam Theory of Planned Behavior, seseorang yang memiliki peluang dan sumber daya yang diperlukan untuk melakukan perilaku, maka akan berhasil melakukannya, di mana pencapaian perilaku bergantung pada motivasi (niat) dan kemampuan (kontrol perilaku) seseorang tersebut (Ajzen, 1991). Teori ini juga menggambarkan adanya niat dan perilaku individu bukan hanya dipengaruhi oleh sikap subjektif namun juga dipengaruhi oleh kemudahan/kesulitan serta berbagai macam alasan yang berbeda yang dihadapi seseorang (Ayudya \& Wibowo, 2018). Ajzen (2005) menunjukkan bahwa terdapat beberapa pertimbangan yang melatarbelakangi suatu perilaku seseorang, yaitu faktor personality, social, dan information. Dalam teori ini, Faktor information relevan untuk menjelaskan variabel literasi keuangan dan financial technology. Faktor social relevan untuk menjelaskan variabel jenis kelamin, usia, pendapatan, dan pendidikan.

\section{Inklusi Keuangan}

Inklusi keuangan merupakan kondisi pada saat seluruh masyarakat dapat mengakses produk dan layanan jasa keuangan (Gardeva \& Rhyne, 2011). Menurut Durai \& Stella (2019), inklusi keuangan adalah sebuah proses memastikan akses layanan keuangan dan kredit yang memadai dengan biaya yang terjangkau. Pengukuran inklusi keuangan dilakukan menggunakan skala guttman untuk indikator formal account dan formal credit dan skala likert untuk indikator formal saving. Skala guttman yang digunakan mempunyai skor 1 atas jawaban "Ya", dan Skor 0 atas jawaban "Tidak". Untuk skala likert 
Adinda Novita Sari \& Achmad Kautsar. Analisis Pengaruh Literasi Keuangan, Financial Technology, dan Demografi terhadap Inklusi Keuangan pada Masyarakat di Kota Surabaya

yang digunakan memiliki rentang skor 1 sampai dengan 4 dengan range jawaban "tidak pernah" hingga "sangat sering". Pernyataan terkait inklusi keuangan meliputi kepemilikan akun dan intensitas penggunakan akun dalam aktivitas sehari-hari.

\section{Literasi Keuangan}

Literasi keuangan merupakan penggabungan dari pengetahuan, keahlian, dan sikap mengenai pengelolaan keuangan (Cohen \& Nelson, 2011). Menurut OECD (2016), literasi keuangan didefinisikan sebagai ketrampilan keuangan dan kepercayaan diri untuk dapat mengambil keputusan yang tepat. Pengukuran literasi keuangan menggunakan indikator dari Chen \& Volpe (1998) yang diukur menggunakan skala likert dan skala guttman. Skala guttman dipakai untuk mengetahui tingkat literasi keuangan masyarakat di Kota Surabaya, dan skala likert digunakan untuk diujikan pengaruhnya terhadap variabel inklusi keuangan. Skala guttman yang digunakan adalah pertanyaan benar atau salah. Skala likert yang digunakan memiliki rentang skor 1 sampai dengan 4 dengan range jawaban "tidak pernah" hingga "sangat sering". Pertanyaan terkait literasi keuangan meliputi pemahaman mengenai risiko investasi, hak dan kewajiban peminjam, tingkat suku bunga, nilai mata uang, dan asuransi.

\section{Financial Technology}

Financial technology merupakan penggabungan sistem di bidang keuangan dengan teknologi yang memungkinkan pembelian dan penjualan produk atau jasa pada waktu yang berbeda dan ruang pasar yang berbeda (Freedman, 2006). Pengukuran financial technology menggunakan indikator dari Davis (1989) yang diukur memakai skala likert. Skala likert yang dipakai mempunyai rentang skor 1 sampai dengan 4 dengan range jawaban "tidak pernah" hingga "sangat sering". Pernyataan terkait financial technology meliputi kemudahan, penggunaan, dan manfaat yang dirasakan oleh responden.

\section{Jenis Kelamin}

Jenis kelamin adalah perbedaan fungsi biologi, sifat dan peran yang dibedakan menjadi laki-laki dan perempuan (Nadliroh, 2017). Pengukuran variabel jenis kelamin termasuk dalam variabel dummy, sehingga laki-laki akan mendapat skor 1, dan perempuan mendapat skor 0.

\section{Usia}

Usia merupakan ukuran yang menggambarkan lamanya masa hidup seseorang yang dihitung sejak waktu kelahiran hingga berulang tahun (Isnandar, 2019). Pengukuran usia dinilai dengan skala rasio 1 sampai dengan 5, di mana semakin rendah klasifikasi usia, maka semakin rendah nilai yang didapat. Usia diklasifikasikan berdasarkan survei (OJK, 2016) yakni usia $15-17$ tahun $=$ skor 1 , usia $18-25$ tahun $=$ skor 2 , usia $26-35$ tahun $=$ skor 3 , usia $36-50$ tahun $=$ skor 4 , dan usia $>50$ tahun $=$ skor 5 .

\section{Pendapatan}

Pendapatan adalah sejumlah penghasilan/gaji yang diterima oleh seseorang atas pekerjaan atau usahanya (Isnandar, 2019). Pengukuran pendapatan dinilai dengan skala ordinal 1 sampai dengan 6, di mana semakin rendah klasifikasi pendapatannya, maka semakin rendah nilainya. Tingkat pendapatan diklasifikasikan berdasarkan penelitian Saputra \& Dewi (2017) yaitu sejumlah $<$ Rp1.000.000 = skor 1, sejumlah Rp1.000.001-Rp2.500.000 = skor 2, sejumlah Rp2.500.001-Rp4.000.000 = skor 3, sejumlah Rp4.000.001-Rp5.500.000 = skor 4, sejumlah Rp5.500.001-Rp7.000.000 = skor 5, dan sejumlah $>$ Rp7.000.000 $=$ skor 6.

\section{Pendidikan}

Pendidikan adalah jenjang atau tahapan pendidikan terakhir yang telah ditamatkan oleh seseorang (Krisnakai, 2017). Pengukuran pendidikan dinilai dengan skala ordinal 1 sampai 7, di mana semakin rendah tingkat pendidikannya, maka semakin rendah pula nilai yang didapat. Tingkat pendidikan diklasifikasikan berdasarkan penelitian Safira \& Dewi (2019) yaitu tingkat SD/ MI = skor 1, tingkat $\mathrm{SMP}=$ skor 2, tingkat SMA $/$ Sederajat $=$ skor 3, tingkat S1/S2/S3 = skor 4, tingkat S2 = skor 5, dan tingkat $\mathrm{S} 3=$ skor 6 . 


\section{Hubungan antar Variabel}

Literasi keuangan merupakan ketrampilan keuangan dan keseluruhan wawasan yang dimiliki seseorang untuk dapat mengelola keuangannya (Asandimitra \& Kautsar, 2020). Seseorang dengan tingkat literasi keuangan yang bagus (well literate), tentu dapat lebih mudah untuk mengaplikasikan informasi termasuk berbagai macam fasilitas, fungsi, dampak kerugian, serta hak dan kewajiban dalam mengakses dan memanfaatkan produk atau layanan jasa keuangan (OJK, 2017). Hal ini akan mendorong seseorang untuk mengenal dan memanfaatkan produk-produk serta layanan jasa keuangan yang diikuti oleh peningkatan keuangan inklusif (Hutabarat, 2018). Dalam penelitian Pulungan \& Ndruru (2019), Hutabarat (2018), dan Bongomin et al. (2016) menemukan hasil positif dan signifikan di mana literasi keuangan mempunyai pengaruh terhadap inklusi keuangan, sehingga dengan literasi keuangan yang cukup bagus, maka kemampuannya untuk mengaplikasikan produk dan layanan keuangan juga semakin bijak.

H1: Literasi keuangan berpengaruh positif terhadap inklusi keuangan pada masyarakat di Kota Surabaya.

Financial technology merupakan penggabungan sistem keuangan dengan teknologi yang menghasilkan produk dan jasa (Freedman, 2006). Ketersediaan Fintech diharapkan dapat diakses dan digunakan oleh masyarakat yang selama ini belum bisa menjangkau layanan keuangan secara efektif sehingga merangsang pertumbuhan keuangan inklusif (Hutabarat, 2018). Dalam penelitian Durai \& Stella (2019), Fanta \& Makina (2019), dan Hutabarat (2018) menemukan hasil di mana financial technology memiliki pengaruh positif pada inklusi keuangan. Hal ini akan mendorong masyarakat jadi lebih mudah dalam penggunaan produk dan layanan jasa keuangan di manapun dan kapanpun untuk dapat tercapai tujuan inklusi keuangan.

H2: Financial technology berpengaruh positif terhadap inklusi keuangan pada masyarakat di Kota Surabaya.

Jenis kelamin didefinisikan sebagai perbedaan biologis dan kedudukan (peran) yang dibagi menjadi dua jenis yakni laki-laki dan perempuan (Nadliroh, 2017). Laki-laki mempunyai tanggung jawab yang lebih besar dalam pengambilan keputusan keuangan dalam sebuah rumah tangga (Rizaldi \& Asandimitra, 2019). Untuk dapat mengambil keputusan yang baik, laki-laki harus mampu dan paham mengenai pengelolaan keuangan yang efektif, di mana hal ini akan mendorong peningkatan akses dan penggunaan produk dan layanan keuangan (Hutabarat, 2018). Penemuan dalam penelitian Fungáčová \& Weill (2014), Zins \& Weill (2016), dan Cámara \& Tuesta (2016) menyatakan bahwa seorang laki-laki lebih berkontribusi pada inklusi keuangan karena mereka secara positif terkait dengan kepemilikan rekening dan melakukan kredit di lembaga keuangan formal.

H3: Jenis kelamin berpengaruh positif terhadap inklusi keuangan pada masyarakat di Kota Surabaya.

Usia didefinisikan sebagai ukuran yang menggambarkan lamanya masa hidup seseorang yang dihitung sejak waktu kelahiran hingga berulang tahun. Seiring bertambahnya usia seseorang, tingkat kematangan berpikirnya dan kekuatannya dalam bekerja akan lebih baik. Usia produktif dimulai pada saat seseorang telah berusia minimal 15 tahun di mana pada tahap ini seseorang telah dianggap mampu untuk mendapatkan penghasilan, dan mengelola keuangannya dengan baik (Humaidi et al., 2020). Dalam rangka meningkatkan kesejahteraannya, maka dorongan untuk dapat mengakses, menggunakan, dan memanfaatkan produk dan layanan jasa keuangan akan semakin aktif sehingga tercapai tujuan keuangan inklusif. Menurut penelitian Hutabarat (2018), Nugroho \& Purwanti (2017), dan Abel et al. (2018) menemukan bahwa usia berpengaruh terhadap inklusi keuangan seseorang, di mana semakin dewasa usia individu, maka akan lebih baik untuk dapat terinklusi keuangannya.

H4: Usia berpengaruh positif terhadap inklusi keuangan pada masyarakat di Kota Surabaya. 
Adinda Novita Sari \& Achmad Kautsar. Analisis Pengaruh Literasi Keuangan, Financial Technology, dan Demografi terhadap Inklusi Keuangan pada Masyarakat di Kota Surabaya

Pendapatan merupakan sejumlah penghasilan yang diterima oleh seseorang atas pekerjaan atau usahanya (Isnandar, 2019). Semakin banyak pendapatan yang diterima oleh seseorang, maka akan semakin besar tanggung jawabnya untuk mengelola uang yang dimiliki dengan bijak (Nugroho \& Purwanti, 2017). Dalam keputusan keuangannya, seseorang dengan pendapatan tinggi memiliki kemungkinan besar untuk memiliki rekening, menabung, dan meminjam menggunakan berbagai macam produk dan layanan keuangan (Hutabarat, 2018). Dalam penelitian Nugroho \& Purwanti (2017), Roy \& Chaterjee (2016), dan Tuesta et al. (2015) menemukan adanya pengaruh positif antara pendapatan dan inklusi keuangan, di mana saat seseorang memiliki pendapatan yang besar, maka akan diikuti dengan peningkatan inklusi keuangannya.

H5: Pendapatan berpengaruh positif terhadap inklusi keuangan pada masyarakat di Kota Surabaya.

Pendidikan diartikan sebagai jenjang atau tahapan pendidikan terakhir yang telah ditamatkan oleh seseorang (Isnandar, 2019). Seseorang yang telah menempuh pendidikan tinggi, memahami berbagai wawasan dan pengetahuan yang luas sehingga kesadaran akan fungsi berbagai macam produk serta layanan jasa keuangan juga lebih tinggi (Abel et al., 2018). Semakin tinggi jenjang pendidikan terakhir yang telah ditempuh seseorang, maka akan semakin tepat pula keputusan keuangannya terlebih untuk kesejahteraan keuangan pribadinya (Nugroho \& Purwanti, 2017). Dalam penelitian Khoirunnisa (2018), Nugroho \& Purwanti (2017), dan Abel et al. (2018) menemukan hasil positif antara tingkat pendidikan seseorang terhadap inklusi keuangan, sehingga semakin terdidik seseorang, akan berpengaruh pada peningkatan inklusi keuangannya.

H6: Pendidikan berpengaruh positif terhadap inklusi keuangan pada Masyarakat di Kota Surabaya.

\section{METODE PENELITIAN}

Penelitian ini termasuk ke dalam jenis penelitian konklusif kausalitas. Variabel inklusi keuangan menjadi variabel terikat dalam penelitian ini, sedangkan variabel literasi keuangan, financial technology, jenis kelamin, usia, pendapatan, dan pendidikan menjadi variabel bebasnya. Sumber datanya ialah menggunakan data primer dengan media berupa kuesioner. Penyebaran kuesioner dilakukan secara online dengan menggunakan google form yang disebarkan melalui media sosial seperti instagram, line dan whats app. Rentang waktu yang dibutuhkan dalam pengumpulan data pada penelitian ini sejak 03 April-30 April 2020. Pengumpulan data yang akan disajikan menggunakan jenis penelitian kuantitatif, di mana data dianalisis dan akan dijelaskan dalam bentuk data numerik. Data yang diperoleh kemudian dianalisis dengan uji validitas dan uji reliabilitas, analisis regresi linier berganda diantaranya uji normalitas, uji multikolinieritas, dan uji heteroskedastisitas serta uji hipotesis dengan menggunakan program SPSS versi 23. Populasi yang digunakan mencakup seluruh masyarakat yang tinggal di Kota Surabaya, baik berdomisili (tidak ber-KTP) maupun memiliki KTP Surabaya. Jumlah indikator dalam penelitian ini berjumlah 13, di mana dalam penentuan jumlah sampel dikalikan 10, maka hasilnya 130 responden. Kemudian jumlah tersebut ditambah $10 \%$ dari hasil sehingga jumlah total dibulatkan menjadi 155 responden. Sampel diambil dengan teknik quota sampling dengan kriteria responden telah berusia 15 tahun atau lebih dan sudah memiliki pendapatan.

\section{HASIL DAN PEMBAHASAN}

\section{Deskriptif Jawaban Responden}

Hasil jawaban dari 155 responden, menunjukkan bahwa responden didominasi oleh masyarakat berjenis kelamin perempuan sebesar 54,2\% yang berjumlah 84 responden, sedangkan untuk presentase paling kecil adalah jenis kelamin laki-laki yaitu sebesar $45,8 \%$ sejumlah 71 responden. Karakteristik individu berdasarkan usia persentase paling besar ditunjukkan oleh individu dengan rentang usia $18-25$ tahun yakni sebesar 48,4\% sejumlah 75 responden, sedangkan untuk persentase paling kecil ditunjukkan oleh individu dengan rentang usia $>50$ tahun yakni sebesar $11 \%$ dengan jumlah 17 responden. Karakteristik individu berdasarkan tingkat pendapatannya, persentase paling besar adalah pada rentang pendapatan $<$ Rp1.000.000 yaitu sebesar 27,1\% dengan jumlah 42 responden, sedangkan untuk persentase paling kecil ada pada rentang pendapatan Rp2.500.001-Rp4.000.000 yaitu sebesar 10,3\% dengan jumlah 16 
responden. Karakteristik responden berdasarkan tingkat pendidikannya, persentase paling besar adalah pada tingkat pendidikan SMA/ Sederajat yakni sebesar 42,6\% sejumlah 66 responden, sedangkan untuk persentase paling kecil berada pada tingkat pendidikan $\mathrm{S} 2$ yakni sebesar 5,1\% sejumlah 8 responden.

Skala likert yang digunakan terhadap responden, menghasilkan beberapa karakteristik jawaban terkait variabel inklusi keuangan, literasi keuangan, dan financial technology. Untuk variabel literasi keuangan, item skor yang memiliki nilai tertinggi yakni IK7 memiliki nilai rata-rata sebesar 2.87 dengan pernyataan "intensitas melakukan penarikan uang dari rekening" yang menandakan bahwa masyarakat secara aktif menggunakan akunnya untuk penarikan uang tunai. Hasil jawaban responden terkait variabel literasi keuangan, item skor yang memiliki nilai tertinggi yakni LK1 memiliki nilai rata-rata sebesar 3.56 dengan pertanyaan "memahami pentingnya pengetahuan keuangan di masa sekarang dan di masa depan" yang menandakan bahwa masyarakat telah memiliki kesadaran yang baik tentang pengetahuan keuangan. Hasil jawaban responden terkait variabel financial technology, item skor yang memiliki nilai tertinggi yakni FT1 memiliki nilai rata-rata sebesar 3.51 dengan pernyataan "merasa mudah menggunakan teknologi di bidang keuangan" yang menandakan bahwa masyarakat dapat menggunakan teknologi di bidang keuangan yang tersedia saat ini dengan mudah.

Hasil jawaban responden yang menggunakan skala guttman terkait variabel inklusi keuangan dan literasi keuangan menghasilkan beberapa karakteristik jawaban. Untuk variabel inklusi keuangan, item pertanyaan IK2 memiliki persentase tertinggi yakni $100 \%$ dengan pertanyaan "memiliki kartu debit atau ATM" yang menandakan bahwa masing-masing responden telah memiliki produk layanan keuangan jenis kartu debit. Hasil jawaban responden terkait variabel literasi keuangan, item pertanyaan mengenai literasi keuangan, rata-rata responden menjawab benar sebesar 94.3\%, sedangkan rata-rata responden menjawab salah sebesar 5.7\%. Berdasarkan kategori yang dikemukakan oleh Chen \& Volpe (1998), hasil pengukuran tingkat literasi keuangan pada penelitian ini sebesar 94.5\%, di mana persentase tersebut masuk dalam kategori tinggi yaitu higher financial literacy.

\section{Uji Validitas}

Hasil uji validitas untuk skala guttman pada variabel inklusi keuangan dan literasi keuangan memperlihatkan di mana variabel tersebut dapat dikatakan valid dikarenakan hasil nilai koefisien telah melampaui kriteria yaitu Koefisien Reprodusibilitas > 0.90 dan Koefisien Skalabilitas > 060. Untuk variabel inklusi keuangan memiliki nilai Koefisien Reprodusibilitas 0.969 dan Koefisien Skalabilitas 0.938. Sedangkan untuk variabel literasi keuangan menghasilkan nilai Koefisien Reprodusibilitas 0.953 dan Koefisien Skalabilitas 0.905. Dari hasil pengukuran menunjukkan bahwa nilai koefisien telah memenuhi syarat validitas. Hasil uji validitas untuk skala likert variabel inklusi keuangan, literasi keuangan, dan financial technology diuji menggunakan aplikasi SPSS. Hasil uji validitas untuk semua item menghasilkan nilai $r_{\text {hitung }}>r_{\text {tabel }}$. Nilai $r_{\text {tabel }}$ pada 30 responden sejumlah 0.3610 dan nilai $r_{\text {tabel }}$ pada 155 responden sejumlah 0.157 . Sehingga jawaban responden dan item pertanyaan dapat dinyatakan valid sehingga dapat diandalkan sebagai alat ukur untuk penelitian ini.

\section{Uji Reliabilitas}

Hasil uji reliabilitas untuk skala guttman dilakukan dengan metode KR-20 terkait variabel inklusi keuangan dan literasi keuangan memiliki nilai > 0.60. Sehingga berdasarkan koefisien reliabilitas guillford menunjukkan bahwa jawaban atau data yang diberikan responden memiliki tingkat reliabilitas tinggi yakni berada pada rentang $0.60-0.80$. Nilai KR-20 untuk variabel inklusi keuangan sebesar 0.634 dan variabel literasi keuangan sebesar 0.617. Dari hasil pengukuran menunjukkan bahwa nilai telah memenuhi syarat. Hasil uji reliabilitas untuk skala likert pada variabel inklusi keuangan, literasi keuangan, dan financial technology menggunakan nilai cronbach's alpha sebesar > 0,60. Nilai cronbach's alpha untuk variabel inklusi keuangan sebesar 0.666, variabel literasi keuangan sebesar 0.806 , dan variabel financial technology sebesar 0.892. Sehingga jawaban atau data yang diberikan responden telah memenuhi kriteria dan dapat dinyatakan reliabel. 
Adinda Novita Sari \& Achmad Kautsar. Analisis Pengaruh Literasi Keuangan, Financial Technology, dan Demografi terhadap Inklusi Keuangan pada Masyarakat di Kota Surabaya

\section{Uji Normalitas}

Hasil uji normalitas menggunakan metode analisis grafik dan uji statistik. Grafik normal probability plot digunakan dalam melakukann analisis grafik, di mana dalam penelitian ini menghasilkan bahwa data menyebar di daerah tidak jauh dari garis diagonal dan searah dengan grafik diagonal atau grafik histogramnya. Pengujian menggunakan uji Kolmogorov-Smirnov (K-S) dilakukan untuk uji statistik yang menghasilkan nilai sebesar 0.065 dan signifikansi sebesar $0.502>0.05$. Sehingga dari nilai yang dihasilkan penelitian ini memiliki data residual berdistribusi normal.

\section{Uji Multikolinieritas}

Hasil uji multikolinieritas menggunakan besaran nilai VIF. Seluruh variabel independen dalam penelitian ini menghasilkan besaran nilai VIF dan nilai tolerance sebesar $<10$ dan $>0.1$. Sehingga dari nilai yang dihasilkan, didapatkan kesimpulkan model regresi pada penelitian ini tidak mengalami gejala multikolinieritas.

\section{Uji Heteroskedastisitas}

Hasil uji heteroskedastisitas dilakukan dengan analisis pengamatan grafik scatterplot dan uji glejser. Pada grafik scatterplot menunjukkan bahwa titik-titik nampak tersebar secara acak baik di bawah dan juga di atas angka 0 terhadap sumbu Y. Uji glejser dilakukan dengan melihat nilai signifikansi dari keseluruhan variabel independen yang menghasilkan menghasilkan nilai $>0,05$. Sehingga dari hasil analisis grafik dan nilai yang dihasilkan, didapatkan kesimpulan bahwa di dalam penelitian ini tidak ditemukan terjadinya gejala heteroskedastisitas.

\section{Regresi Linier Berganda}

Hasil regresi linier berganda pada penelitian ini membentuk persamaan regresi (1). Persamaan (1) memperlihatkan hasil besarnya nilai konstanta sebesar 1.813 yang menerangkan bahwa keseluruhan variabel dianggap konstan, maka nilai inklusi keuangan ada masyarakat di Kota Surabaya sebesar 1.813. Besarnya koefisien regresi literasi keuangan senilai 0.293 mengindikasikan setiap penaikan sebanyak 1000 kali maka akan meningkatkan inklusi keuangan sebanyak 293 kali. Nilai koefisien regresi variabel usia senilai 0.611 yang berarti setiap penaikan sebanyak 1000 kali maka akan meningkatkan inklusi keuangan sebanyak 611 kali. Nilai koefisien regresi variabel tingkat pendidikan senilai 0.577 yang berarti setiap penaikan sebanyak 1000 kali maka akan meningkatkan inklusi keuangan sebanyak 577 kali.

$Y=1,813+0,293 L K+0,577 T P+e$

\section{Uji Statistik F}

Hasil uji $F$ menerangkan bahwa nilai $F_{\text {hitung }}$ sebesar 10.880 dengan probabilitas 0.000. Dapat diartikan bahwa semua variabel independen secara bersama-sama mempengaruhi inklusi keuangan.

\section{Uji Statistik T}

Tabel 1 menunjukkan hasil uji statistik $\mathrm{T}$ menghasilkan nilai $\mathrm{t}_{\text {hitung }}$ variabel literasi keuangan sebesar

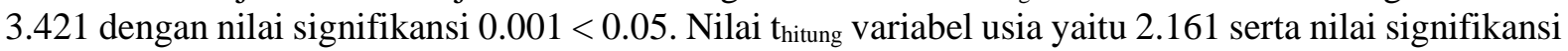

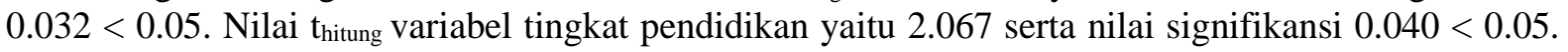
Dari hasil yang didapatkan, maka ketiga variabel tersebut signifikan terhadap inklusi keuangan. Maka keputusannya adalah terima $\mathrm{H} 1$ dan tolak H0. Sedangkan untuk variabel financial technology, jenis kelamin, dan pendapatan tidak signifkan terhadap inklusi keuangan karena memiliki nilai signifikansi $>0.05$ sehingga terima $\mathrm{H} 0$ dan tolak $\mathrm{H} 1$.

\section{Uji Determinasi}

Uji koefisien determinasi pada penelitian ini menghasilkan nilai Adjusted $R$ Square senilai 0.278 atau $27.8 \%$, di mana angka ini dapat diartikan bahwa variabel independen menjelaskan sebanyak $27.8 \%$ terhadap variabel dependen, sedangkan sebanyak $72.2 \%$ dijelaskan oleh variabel independen lain selain yang ada dalam penelitian ini. 


\section{Pengaruh Literasi Keuangan terhadap Inklusi Keuangan}

Literasi keuangan berpengaruh positif terhadap inklusi keuangan pada masyarakat di Kota Surabaya disebabkan karena tingkat literasi keuangan masyarakat yang termasuk dalam kategori higher financial literacy dan juga memiliki tingkat kesadaran yang tinggi mengenai pentingnya pengetahuan dan ketrampilan keuangan baik di masa sekarang maupun masa depan, sehingga bisa menggunakan produk dan layanan keuangan dengan bijak serta dapat mengambil keputusan dengan tepat. Pemerintah dan lembaga keuangan dalam implikasi praktisnya, dirasa perlu memperhatikan mengenai tingkat literasi keuangan masyarakat karena dapat mempengaruhi peningkatan inklusi keuangan. Hal ini searah dengan peneilitian Yakubu et al. (2017), Mindra \& Moya (2017), Saputra \& Dewi (2017), Bongomin et al. (2016), Pulungan \& Ndruru (2019), dan Hutabarat (2018) yang menemukan adanya pengaruh positif antara literasi keuangan terhadap inklusi keuangan.

Tabel 1

\section{HASIL UJI STATISTIK T}

\begin{tabular}{|c|c|c|c|c|c|}
\hline \multirow[t]{2}{*}{ Model } & \multicolumn{2}{|c|}{$\begin{array}{c}\text { Unstandardized } \\
\text { Coefficients }\end{array}$} & \multirow{2}{*}{$\begin{array}{c}\text { Standardized } \\
\text { Coefficients } \\
\text { Beta } \\
\end{array}$} & \multirow[t]{2}{*}{$\mathbf{t}$} & \multirow[t]{2}{*}{ Sig. } \\
\hline & $\mathbf{B}$ & Std. Error & & & \\
\hline (Constant) & 1.813 & 1.890 & & 0.960 & 0.339 \\
\hline Literasi Keuangan & 0.293 & 0.086 & 0.356 & 3.421 & 0.001 \\
\hline Financial Technology & -0.040 & 0.096 & -0.087 & -0.422 & 0.674 \\
\hline Jenis Kelamin & 0.132 & 0.426 & 0.022 & 0.310 & 0.757 \\
\hline Usia & 0.611 & 0.283 & 0.212 & 2.161 & 0.032 \\
\hline Pendapatan & -0.77 & 0.179 & -0.045 & -0.431 & 0.667 \\
\hline Pendidikan & 0.577 & 0.279 & 0.176 & 2.067 & 0.040 \\
\hline
\end{tabular}

Sumber: Output SPSS (Data diolah)

\section{Pengaruh Financial Technology terhadap Inklusi Keuangan}

Financial Technology tidak terbukti berpengaruh terhadap inklusi keuangan, artinya hipotesis kedua (H2) tidak terdukung. Theory of Planned Behavior tidak terbukti terdukung dalam penelitian ini sebagai dasar teori dari variabel financial technology yang dijelaskan melalui salah satu faktor di mana informasi, aplikasi, atau alat berupa teknologi dalam berbagai macam jenis digunakan untuk memahami bagaimana individu berperilaku. Dalam teori ini dapat dinyatakan bahwa dengan tersedianya teknologi keuangan yang mudah digunakan dan manfaat yang ditawarkan, akan mendorong seseorang untuk menggunakan berbagai macam produk atau layanan keuangan pada lembaga keuangan.

Financial technology tidak berpengaruh terhadap inklusi keuangan pada masyarakat di Kota Surabaya disebabkan karena masyarakat belum secara aktif menggunakan fintech untuk mengakses akun pada lembaga perbankan untuk menabung dan meminjam diantaranya debit card, credit card, m-banking, dan internet banking, melainkan menggunakan fintech untuk mengakses produk dan layanan lain yang tidak mendorong keuangan inklusif. Pemerintah dan lembaga keuangan dalam implikasi praktisnya, dirasa perlu memperhatikan faktor lain selain financial technology untuk dapat meningkatkan inklusi keuangan. Hal ini searah dengan penelitian Michelle (2016) yang menemukan bahwa financial technology tidak berpengaruh secara signifikan terhadap inklusi keuangan.

\section{Pengaruh Jenis Kelamin terhadap Inklusi Keuangan}

Jenis kelamin seseorang tidak terbukti berpengaruh terhadap inklusi keuangan, artinya hipotesis ketiga (H3) tidak terdukung. Theory of Planned Behavior tidak terbukti terdukung dalam penelitian ini sebagai dasar teori variabel jenis kelamin yang dijelaskan melalui salah satu faktor di mana kondisi sosial seseorang yakni laki-laki dan perempuan yang memiliki peran yang berbeda, digunakan untuk memahami bagaimana individu berperilaku. Dalam teori ini dapat ditunjukkan bahwa perbedaan di antara laki-laki dan perempuan menyebabkan terjadinya variasi peran dalam kehidupan sosialnya, di mana hal tersebut akan berpengaruh terhadap cara berpikir dan pengambilan keputusan keuangannya. 
Adinda Novita Sari \& Achmad Kautsar. Analisis Pengaruh Literasi Keuangan, Financial Technology, dan Demografi terhadap Inklusi Keuangan pada Masyarakat di Kota Surabaya

Jenis kelamin seseorang tidak berpengaruh terhadap inklusi keuangan pada masyarakat di Kota Surabaya disebabkan karena baik untuk laki-laki dan perempuan tidak mempunyai hambatan yang dibedakan untuk dapat memperoleh kebebasan dalam mengakses dan menggunakan produk atau layanan keuangan pada lembaga keuangan. Pemerintah dan lembaga keuangan dalam rangka meningkatkan inklusi keuangan masyarakat tidak perlu membedakan antara laki-laki dan perempuan dalam memberikan informasi maupun fasilitas. Hal ini searah dengan penelitian Nugroho \& Purwanti (2017) dan Akileng et al. (2018) yang menjelaskan bahwa jenis kelamin tidak memiliki pengaruh terhadap tingkat inklusi keuangan seseorang.

\section{Pengaruh Usia terhadap Inklusi Keuangan}

Usia seseorang terbukti berpengaruh terhadap inklusi keuangan, artinya hipotesis ketiga $(\mathrm{H} 3)$ terdukung. Theory of Planned Behavior terbukti terdukung dalam penelitian ini sebagai dasar teori variabel usia yang dijelaskan melalui salah satu faktor di mana kondisi sosial seseorang yakni tahapan usia individu berada, digunakan untuk memahami bagaimana individu berperilaku. Dalam teori ini dapat diterangkan bahwa seseorang semakin dewasa, akan memiliki tingkat kematangan berpikir yang lebih baik dan membutuhkan produk dan layanan keuangan secara aktif untuk memiliki akun, membuka tabungan, dan melakukan kredit pada lembaga keuangan formal untuk meningkatkan kesejahteraannya.

Usia seseorang berpengaruh terhadap inklusi keuangan pada masyarakat di Kota Surabaya disebabkan karena responden yang mendominasi ialah individu dengan rentang usia 18-25 tahun, di mana pada usia tersebut seseorang baru memasuki tahap usia dewasa. Pada usia tersebut, seseorang berada pada fase telah menyelesaikan pendidikannya, mulai mendapatkan pekerjaan atau memulai usahanya, dan akan berumah tangga sehingga kebutuhan akan produk dan layanan keuangan semakin meningkat. Sehingga pemerintah dan lembaga keuangan perlu untuk memperhatikan faktor usia seseorang untuk dapat meningkatkan inklusi keuangan. Hal ini sejalan dengan penelitian dari Akileng et al. (2018), Zins \& Weill (2016), Abel et al., 2018), (Tuesta et al., 2015), (Hutabarat, 2018), dan (Nugroho \& Purwanti, 2017) yang menemukan bahwa jenis kelamin tidak memiliki pengaruh terhadap inklusi keuangan seseorang.

\section{Pengaruh Pendapatan terhadap Inklusi Keuangan}

Pendapatan seseorang tidak terbukti memiliki pengaruh terhadap inklusi keuangan, artinya hipotesis keempat (H4) tidak terdukung. Theory of Planned Behavior tidak terbukti terdukung dalam penelitian ini sebagai dasar teori variabel pendapatan yang dijelaskan melalui salah satu faktor di mana kondisi sosial seseorang yakni jumlah penghasilan yang diterima atas pekerjaanya, digunakan untuk memahami bagaimana individu berperilaku. Dalam teori ini dapat ditunjukkan bahwa pendapatan seseorang semakin tinggi, menyebabkan penghasilan tersebut akan digunakan untuk mengakses produk dan layanan keuangan seperti memiliki akun, menabung, dan melakukan kredit pada lembaga keuangan formal untuk dapat terinklusi keuangannya.

Pendapatan seseorang tidak berpengaruh terhadap inklusi keuangan pada masyarakat di Kota Surabaya disebabkan karena responden yang berpendapatan rendah memiliki keterbatasan dalam menggunakan uangnya namun memiliki kemampuan pengelolaan keuangan yang baik, sedangkan individu dengan pendapatan tinggi cenderung lebih konsumtif untuk dapat memenuhi kebutuhan gaya hidupnya. Oleh karena itu perbedaan tingkat pendapatan tidak akan membuat perbedaan tingkat inklusi keuangannya. Sehingga pemerintah dan lembaga keuangan dalam rangka meningkatkan inklusi keuangan tidak perlu memperhatikan jumlah pendapatan seseorang maupun kelompok. Hasil ini searah dengan penelitian dari Hutabarat (2018) di mana pendapatan ditemukan tidak memiliki pengaruh terhadap inklusi keuangan.

\section{Pengaruh Pendidikan terhadap Inklusi Keuangan}

Pendidikan seseorang terbukti berpengaruh terhadap inklusi keuangan, artinya hipotesis kelima (H5) terdukung. Theory of Planned Behavior terbukti terdukung dalam penelitian ini sebagai dasar teori variabel pendidikan yang dijelaskan melalui salah satu faktor di mana kondisi sosial seseorang yakni jenjang pendidikan terakhir yang telah ditempuh seseorang, digunakan untuk memahami bagaimana individu berperilaku. Dalam teori ini dapat dijelaskan bahwa semakin tinggi tingkatan seseorang untuk 
menamatkan pendidikan terakhirnya, membuat wawasan dan kemampuan pengelolaan keuangannya semakin baik dalam memanfaatkan produk dan layanan keuangan.

Pendidikan seseorang berpengaruh terhadap inklusi keuangan pada masyarakat di Kota Surabaya disebabkan karena setiap tingkat pendidikan memiliki tahapan perkembangan, tingkat kesulitan, bahan pengajaran, dan cara penyajian yang berbeda pula, sehingga kualitas pengetahuan dan ketrampilan ilmu yang diperoleh seseorang akan semakin baik. Dengan pendidikan yang tinggi, maka akan semakin luas wawasan dan edukasi keuangan seseorang mengenai produk, jasa, fasilitas, fungsi, dampak kerugian, serta hak dan kewajiban sebagai pengguna produk dan layanan keuangan. Sehingga pemerintah dan lembaga keuangan perlu untuk memperhatikan tingkat pendidikan seseorang agar dapat menggunakan produk dan layanan keuangan dengan baik. Hasil ini searah dengan penelitian Fungáčová \& Weill (2014), Roy \& Chaterjee (2016), Zins \& Weill (2016), Abel et al. (2018), Cámara \& Tuesta (2016), Sahoo et al. (2017), Tuesta et al. (2015), Khoirunnisa (2018), dan Nugroho \& Purwanti (2017) yang menemukan hasil yakni tingkat pendidikan seseorang memiliki pengaruh terhadap inklusi keuangan.

\section{KESIMPULAN}

Faktor literasi keuangan merupakan faktor yang paling berpengaruh terhadap inklusi keuangan masyarakat di Kota Surabaya, yakni pencapaian keuangan inklusif sangat dipengaruhi oleh tingkat pemahaman dan ketrampilan pengelolaan keuangan seseorang hingga dapat mengakses produk dan layanan keuangan secara bijak. Selain itu, faktor usia dan tingkat pendidikan juga mempengaruhi inklusi keuangan masyarakat di Kota Surabaya. Sedangkan untuk faktor financial technology, jenis kelamin, dan pendapatan diketahui tidak memberikan pengaruh terhadap inklusi keuangan masyarakat di Kota Surabaya.

Penelitian ini memberikan hasil yang diharapkan bisa digunakan untuk bahan pertimbangan, pengembangan strategi, maupun pengambilan kebijakan oleh beberapa pihak terkait. OJK diharapkan dapat bersama-sama dengan Bank Indonesia membuat program edukasi keuangan, manfaat dan risiko mengenai produk dan layanan keuangan, serta pelatihan manajemen keuangan kepada pelajar atau mahasiswa, masyarakat umum, dan para pelaku usaha atau UMKM dalam rangka meningkatkan literasi keuangan. Selain itu, lembaga pendidikan seperti sekolah hingga tingkatan perguruan tinggi memiliki peran penting untuk dapat menanamkan pemahaman dan ketrampilan pengelolaan keuangan sejak dini baik akademik maupun non akademik dengan memberikan pembelajaran mengenai perencanaan keuangan, pengelolaan pendapatan, budaya menabung, dan risiko dalam setiap pengambilan keputusan keuangan.

Penelitian ini masih memiliki keterbatasan terkait kurangnya variabel independen yang digunakan. Penelitian selanjutnya dapat menambahkan variabel pekerjaan, status pernikahan, kepercayaan, serta jumlah lembaga keuangan terdekat. Proses wawancara terhadap responden dirasa juga perlu dilakukan. Penggunaan model yang lebih akurat dapat dilakukan seperti menggunakan model mediasi, dan juga memperluas cakupan penelitian dengan mengambil sampel sebanyak mungkin agar ditemukan hasil yang lebih konkrit.

\section{DAFTAR PUSTAKA}

Abel, S., Mutandwa, L., \& Roux, P. Le. (2018). A Review of Determinants of Financial Inclusion. International Journal of Economics and Financial Issues, 8(3), 1-8.

Ajzen, I. (1991). The Theory of Planned Behavior. Organizational Behavior and Human Decision Processes, 50, 179-211. https://doi.org/https://doi.org/10.1016/0749-5978(91)90020-T 3.

Ajzen, I. (2005). Attitudes, Personality, and Behavior (Second Edition) (T. Manstead (ed.); 2nd ed.). Open University Press. 
Adinda Novita Sari \& Achmad Kautsar. Analisis Pengaruh Literasi Keuangan, Financial Technology, dan Demografi terhadap Inklusi Keuangan pada Masyarakat di Kota Surabaya

Akileng, G., Lawino, G. M., \& Nzibonera, E. (2018). Evaluation of determinants of financial inclusion in Uganda. Journal of Applied Finance \& Banking, 8(4), 47-66.

Asandimitra, N., \& Kautsar, A. (2020). The Influence of Financial Information, Financial Literacy, Financial Self-Efficacy, and Emotional Intelligence to Financial. Humanities \& Sosial Sciences Reviews, 7(6), 1112-1124. https://doi.org/https://doi.org/10.18510/hssr.2019.76160

Atkinson, A., \& Messy, F.-A. (2012). Measuring Financial Literacy: Results of the OECD / International Network on Financial Education ( INFE) Pilot Study (No. 15). https://doi.org/Adele Atkinson, Flore-Anne Messy https://dx.doi.org/10.1787/5k9csfs90fr4-en

Ayudya, A. C., \& Wibowo, A. (2018). The Intention to Use E-Money using Theory of Planned Behavior and Locus of Control. Jurnal Keuangan Dan Perbankan, 22(2), 335-349. https://doi.org/10.26905/jkdp.v22i2.1691

Bongomin, G. O. C., Ntayi, J. M., Munene, J. C., \& Nkote Nabeta, I. (2016). Social capital: Mediator of Financial Literacy and Financial Inclusion in Rural Uganda. Review of International Business and Strategy, 26(2), 291-312. https://doi.org/10.1108/RIBS-06-2014-0072

Cámara, N., \& Tuesta, D. A. (2016). Factors that matter for financial inclusion : Evidence from Peru. AESTIMATIO, The IEB International Journal of Finance, 2015. 10: 8-29 @, January 2015. https://doi.org/10.5605/IEB.10.1

Chen, H., \& Volpe, R. P. (1998). An Analysis of Personal Financial Literacy Among College Students. Financial Services Riview, 7(2), 107-128.

Cohen, M., \& Nelson, C. (2011). Financial Literacy : A Step for Clients towards Financial Inclusion. Commissioned Workshop Paper, Valladolid, Spain.

Davis, F. D. (1989). Percevid Usefulness, Percevid Ease of Use, and user Acceptance of Information Technology. MIS Quarterly, 319-340. http://www.jstor.org/pagr/info/about/policies/terms.jsp

Demirgüç-Kunt, A., Klapper, L., Singer, D., Ansar, S., \& Hess, J. (2018). The little book on Financial Inclusion 2018. World Bank Group. Finance \& Market. https://www.unsgsa.org/files/3815/2511/8893/LDB_Financial_Inclusion_2018.pdf

Durai, T., \& Stella, G. (2019). Digital Finance and Its Impact on Financial Inclusion. Research Gate, January. https://mpra.ub.uni-muenchen.de/84771/

Fanta, A., \& Makina, D. (2019). The Relationship Between Technology and Financial Inclusion : CrossSectional Evidence. Extending Financial Inclusion in Africa, June, 211-230. https://doi.org/10.1016/b978-0-12-814164-9.00010-4

Freedman, R. S. (2006). Complete Technology Guides For Financial Service Series to Introduction Financial Technology (1st ed.). Academics Press. https://books.google.co.id/books?hl=id\&lr=\&id=APJ7QeR_XPkC\&oi=fnd\&pg=PP1\&dq=finan cial+technology\&ots=fPSN2_cstW\&sig=z7SoOPHOF1gd_Non2mNGgO6uAPI\&redir_esc=y\#v =onepage \&q=financial\%20technology \&f=false, diakses pada 11 Desember 2019.

Fungáčová, Z., \& Weill, L. (2014). Understanding financial inclusion in China. China Economic Review, 34, 196-206. https://doi.org/10.1016/j.chieco.2014.12.004

Gardeva, A., \& Rhyne, E. (2011). Opportunities and Obstacles to Financial Inclusion. Publication 12 Center for Financial Inclusion at Accion International. 1-46. 
Hanung, R. (2018). Terbukti, Surabaya Memang Sarang Orang Kaya RI. CNBC Indonesia. https://www.cnbcindonesia.com/news/20180923150139-4-34365/terbukti-surabaya-memangsarang-orang-kaya-ri, diakses pada 11 Desember 2019.

Humaidi, A., Khoirudin, M., Riska, A., \& Kautsar, A. (2020). The Effect of Financial Technology , Demography, and Financial Literacy on Financial Management Behavior of Productive Age in Surabaya , Indonesia. International Journal of Advances in Scientific Research and Engineering (Ijasre), 6(1), 77-81. https://doi.org/10.31695/IJASRE.2020.33604

Hutabarat, F. (2018). Pengaruh literasi keuangan dan financial technology terhadap inklusi keuangan pada masyarakat jabodetabek. Institut Pertanian Bogor. 1-41.

Ion, \& Alexandra. (2016). Financial Technology (FinTech) and its Implementation on the Romanian Non-Banking Capital Market. SEA - Practical Application of Science, IV(11), 379-384.

Isnandar. (2019). Pengaruh Demografi dan Suku Bunga Terhadap Perilaku Menabung Masyarakat di Kabupaten Pamekasan. Jurnal Ilmu Manajemen (JIM), 7(4), 994-1004.

Khoirunnisa, I. (2018). Analisis Kausalitas Inklusi Keuangan Terhadap Pertumbuhan Inklusif di Indonesia [Universitas Sumatra Utara]. In Repositori Institusi USU. http://repositori.usu.ac.id/handle/123456789/12535

Krisnakai. (2017). Pengertian Tingkat Pendidikan. Bukuteori.Com. https://bukuteori.com/2017/05/20/pengertian-tingkat-pendidikan/, diakses pada 11 Desember 2019.

Kusnandar, V. B. (2019). Inilah Sebaran Penduduk Miskin di Indonesia 2019. Databoks. https://databoks.katadata.co.id/datapublish/2019/07/31/inilah-sebaran-penduduk-miskin-diindonesia-2019, diakses pada 15 November 2019.

Michelle, A. M. (2016). The Effect of Digital Finance on Financial Inlusion in the Banking Industry in Kenya. University of Nairobi. 1-48

Mindra, R., \& Moya, M. (2017). Financial self-efficacy: A mediator in advancing financial inclusion. Equality, Diversity and Inclusion, 36(2), 128-149. https://doi.org/10.1108/EDI-05-2016-0040

Nadliroh, I. (2017). Kesetaraan Gender antara Jenis Kelamin (Seks) dan Pembagian Peran (Gender). Kompasiana.

https://www.kompasiana.com/iinnadliroh/59da41b882386a479e309172/kesetaraan-genderantara-jenis-kelamin-seks-dan-pembagian-peran-gender?page=all, diakses pada 03 Januari 2020

Nugroho, A., \& Purwanti, E. Y. (2017b). Determinan Inklusi Keuangan di Indonesia. Universitas Diponegoro.

OECD. (2016). PISA 2015 Assessment and Analytical Framework: Science, Reading, Mathematic and Financial Literacy (pp. 9-197). OECD Publishing. https://doi.org/http://dx.doi.org/10.1787/9789264255425-en

OJK. (2016). Survei Literasi dan Inklusi Keuangan 2016. Otoritas Jasa Keuangan. 1-26.

OJK. (2017). Strategi Nasional Literasi Keuangan Indonesia (Revisit 2017). Otoritas Jasa Keuangan, $1-99$.

Pulungan, D. R., \& Ndruru, A. (2019). Pengaruh Literasi Keuangan dan Modal Sosial Terhadap Inklusi Keuangan (Studi Kasus pada Mahasiswa Fakultas Ekonomi dan Bisnis Universitas 
Adinda Novita Sari \& Achmad Kautsar. Analisis Pengaruh Literasi Keuangan, Financial Technology, dan Demografi terhadap Inklusi Keuangan pada Masyarakat di Kota Surabaya

Muhammadiyah Sumatera Utara. In Seminar Nasional \& Call For Paper Seminar Bisnis Magister Manajemen (SAMBIS-2019). Universitas Muhammadiyah Sumatera Utara.

Rizaldi, M. H., \& Asandimitra, N. (2019). Demografi, Pengaruh Bekerja, Pengalaman Pendidikan, D A N Keuangan, Pengelolaan Tua, Orang Literasi, Terhadap Di, Mahasiswa Tinggi, Perguruan. Jurnal Ilmu Manajemen Volume 7 Nomor 2 - Jurusan Manajemen Fakultas Ekonomi Universitas Negeri Surabaya, 7(2), 291-298.

Roy, M., \& Chaterjee, T. B. (2016). An analysis of financial inclusion. Journal of Rural Development, $35(4), 621-644$.

Safira, N., \& Dewi, A. S. (2019). Peran Modal Sosial Sebagai Mediator Literasi Keuangan dan Inklusi Keuangan di Kota Padang. Jurnal Mitra Manajemen, 3(1), 29-43. http://ejurnalmitramanajemen.com/index.php/jmm/article/view/125/69

Sahoo, A. K., Pradhan, B. B., \& Sahu, N. C. (2017). Determinants of Financial Inclusion in Tribal Districts of Odisha: An Empirical Investigation. SAGE Publications, 47(1), 1-20. https://doi.org/10.1177/0049085716683072

Saputra, R. S., \& Dewi, A. S. (2017). Peran Modal Sosial Sebagai Mediator Literasi Keuangan dan Inklusi Keuangan Pada Kaum Muda di Indonesia (Studi Kasus pada Komunitas Investor Saham Pemula). Jurnal Manajemen Teori Dan Terapan | Journal of Theory and Applied Management, 10(3), 243. https://doi.org/10.20473/jmtt.v10i3.3064

Sari, D. K. (2017). Analisis Pengaruh Inklusi Keuangan Terhadap Pertumbuhan Ekonomi, Kemiskinan dan Ketimpangan di Jawa Timur Periode tahun 2011-2015. Universitas Brawijaya.

Tuesta, D., Sorensen, G., \& Haring, A. (2015). Financial inclusion and its determinants : the case of Argentina (Issue January). 1-28

Uchoa, P. (2018). Krisis Ekonomi 2008 dan Keadaannya di Sejumlah Negara, termasuk Indonesia, 10 tahun kemudian. BBC World Service. https://www.bbc.com/indonesia/dunia-45495304

Widarti, P. (2020). Pertumbuhan Ekonomi Jatim Capai 5,5 Persen pada 2019. Bisnis.Com. https://surabaya.bisnis.com/read/20200205/532/1197697/pertumbuhan-ekonomi-jatim-capai552-persen-pada-2019

Wildan, M. (2019). Pengaruh Persepsi Kemudahan Penggunaan, Efektivitas dan Risiko terhadap Minat Bertransaksi Menggunakan Financial Technology (Fintech). Universitas Islam Negeri Walisongo. Semarang. 1-71

Wokabi, V. W., \& Fatoki, O. I. (2019). Determinants of Financial Inclusion in East Africa. International Journal of Business and Management, VII(1). https://doi.org/10.20472/bm.2019.7.1.009

Yakubu, I., Dinye, R., Buor, D., \& Iddrisu, W. A. (2017). Discriminant Analysis of Demand-Side Roadblocks to Financial Inclusion in Northern Ghana. Journal of Mathematical Finance, 07(03), 718-733. https://doi.org/10.4236/jmf.2017.73038

Zins, A., \& Weill, L. (2016). The determinants of financial inclusion in Africa. Review of Development Finance, 6(1), 46-57. https://doi.org/10.1016/j.rdf.2016.05.001 